\title{
Multiculturalismo / Multiculturalism
}

https://doi.org/10.21814/uminho.ed.36.45

\section{Ilknur Oner}

Department of Sociology, Faculty of Humanities and Social Sciences, Firat University, Elazıg/Turkey 



\section{Multiculturalismo}

O multiculturalismo é um conceito, uma ideia, uma abordagem que é bastante dinâmica e está associada a diferentes conceitos e relações em contextos diversificados. Num dado tempo e lugar, o seu alcance revela características diferentes de acordo com o seu entendimento, significado e objetivo nas condições históricas, políticas, sociais, económicas e culturais emergentes. Assim, multiculturalismo é um termo complexo que tem sinónimos ou terminologia aproximada em campos de estudo relacionados. Nomeadamente: diversidade, pluralismo, etnia, raça, imigração, religião, opressão, minoria, domínio, pressão, autoridade, desigualdade, igualdade, idade, poder, valores, normas, estatuto, identidade, cidadania, colonização, entendimento/esclarecimento, etnocentrismo, classe, discriminação, vulnerabilidade, risco, subordinação, desvantagem, inclusão, exclusão, envolvimento, participação, empowerment, assimilação, neutralização, padrão, variedade, consciencialização, sensibilizado, dessensibilizado, consciência, ignorância, reconhecimento, herança, legitimação, superioridade, tradições, diálogo, redestribuição de recursos, ética, política, interculturalidade, coesão, conflito, direitos, justiça, etc.

Treppe, Fu e Stremmel indicaram que as consequências de conflitos, guerras ou problemas ambientais extremos, onde quer que seja no mundo, nos estão a afetar, enquanto membros de culturas múltiplas. A raça, a etnia, o género, a idade, a religião, o estatuto laboral, socioeconómico e o contexto familiar definem estas culturas. As diferentes crenças, perceções e comportamentos (culturalmente prescritos ou expectáveis) estão a influenciar a nossa participação na sociedade. São necessárias estratégias que permitam aos seus membros chegarem a um entendimento, independentemente dos seus contextos étnicos, nacionais ou religiosos. Gostemos ou não; não importa. 0 desenvolvimento de uma consciência de acontecimentos interdependentes, de relações e uma abordagem multicultural são, portanto, essenciais (1993, pp. 3- 4; 38- 39).

As raízes do multiculturalismo assentam profundamente na História. Em estudos anteriores focaram-se na identidade e a sua ligação com a construção das nações, cultura dominante e subordinação dos outros, melting pot de assimilação, opressão, colonização, integração cultural, relações de 
poder, as políticas eram pontos essenciais para a emergência de abordagens multiculturais. Um exemplo da diversidade cultural mencionada é a escolarização das crianças nativas iroquesas pelos colonos brancos dominadores e a oposição a isso, em 1744, nos Estados Unidos. Os anos 1960 e 1970 têm crescentes alterações através de uma mudança para legislação multicultural (Canadá, Austrália e outros). No final dos anos 1980 tornaram-se mais sistemáticos os exemplos de pesquisa multicultural (um estudo em Gelsenkirchen, na Alemanha com crianças e mães turcas sobre as necessidades de grupos imigrantes, de grupos minoritários, em 1985) (Treppteke, Fu \& Stremmel, 1993, pp. 1-2).

Os exemplos atuais são sobre experiências de países, grupos, a entrada do multiculturalismo na legislação nacional e transnacional (internacional), as aplicações e os seus resultados, mudanças e renovação, as atividades que afetam as abordagens multiculturais, a sua aceitação e as avaliações delas (o ataque às Torres Gémeas, a 11 de setembro de 2001; o ataque bombista de Londres, em 2005; o ataque de Christchurch na Nova Zelândia, a 15 de março de 2019; a visualização do corpo do sírio Aylan Kurdi na praia de Bodrum, em setembro de 2015, na Turquia; A Tolerância Zero na fronteira México-EUA e a separação das crianças dos pais e a colocação das crianças em acolhimento ou em alojamento temporário, em maio de 2018).

O termo era usado em si mesmo com conotações diferentes, mas os exemplos mais antigos estão sob a égide dos Estudos Indígenas, nos EUA. Richter resume as raízes do termo multiculturalismo na experiência canadiana em 1964 com os termos Sociedade Multicultural, do sociólogo Charles Hobart (Estudos Eslavos) e Nação Multicultural de Paul Yuzyk. Yuzyk, refere Hobart e combina as suas ideias e as de Hobart e recusa chamar-lhe biculturalismo canadiano e chama multiculturalismo ao Programa político do Novo Canadá (2011, pp. 35-37).

A literatura contemporânea sobre o multiculturalismo exemplifica os seguintes públicos-alvo: minorias de imigrantes, pessoas à procura de asilo, trabalhadores migrantes, minorias nacionais, nativos, grupos etnoculturais, representantes, adultos, famílias, mulheres e, mais recentemente, crianças (habitualmente educação e traumas), etc. Várias correntes convencionais de abordagens multiculturalistas são multiculturalistas liberais, críticos multiculturais de inspiração marxista, abordagens feministas ao multiculturalismo, multiculturalismo crítico, Escola Bristol, etc. 
Contudo, a Convenção sobre os Direitos das Crianças foi o ponto de viragem da inclusão das crianças em assuntos relacionados com o que se está a discutir e o desenvolvimento de instituições, organizações e grupos de estudo associadas à temática.

Os trabalhos apresentados no âmbito da Associação Internacional de Sociologia (ISA), no Research Committe 53 (RC53) revelam que os tópicos das crianças, infância e infâncias se têm, gradualmente, tornado no assunto central desde a periferia, desde a sua representação pelos adultos, pais, familiares, Estados, de recetores passivos até à ideia atual de seres humanos ativos. As representações acerca das crianças têm tido lugar desde meados dos anos 1980 e houve um aumento significativo nos anos 1990. Jens Qvortrup revela que a descoberta da infância aconteceu nos anos 1980 por Hengst (1981), Jenks (1982), Corsaro (1985), Qvortrup (1985), Zelizer (1985) e Thorne (1987) como uma categoria sociológica.

Com o tempo, os estudos focaram-se na desigualdade, identidade, imigração, na mobilidade dentro de um determinado contexto e em estádios de vida específicas, diversidade, discriminação, multilinguismo, transnacionalidade, multiculturalidade. Estudos de caso apresentados individualmente foram agregados depois de conferências e congressos e atitudes colaborativas de membros da Sociologia da Infância começaram a ampliar-se.

Desde 2010 há uma tendência crescente para estudar e apresentar infâncias e experiências culturalmente diversas, indicando o perigo de uma abordagem sociológica dominante que exclui a importância das que são ignoradas, das vozes não ouvidas das crianças e das pessoas que as estudam.

O ano de 2010 e especialmente 2017, 2018 e 2019 são anos frutíferos em notas, artigos e livros publicados sobre elas. Estas novas publicações põem o foco, esmagadoramente, nas crianças através da diversidade, multiculturalidade, intersecções, desigualdade, globalização, colonização, tolerância zero nas fronteiras, conflitos de guerra no lémen e na Síria, crianças refugiadas, justiça social, poder, violência, crianças de outros países perto de outros, discussão de problemas de longo curso, etc. (RC 53, 2019). Parece que, dada a atual e injusta desigualdade social, as condições económicas e políticas da nossa era, o multiculturalismo, as crianças e as infâncias vão ter a sua importância nas discussões em ligação com outros conceitos nos nossos estudos. 


\section{Multiculturalism}

Multiculturalism is a concept, an idea, and an approach that is dynamic and linked to different concepts and relations in differing contexts. In a given time and location, its coverage reveals different facets according to the way it is understood, its meaning, and purpose in emerging historical, political, social, economic and cultural conditions. Therefore, multiculturalism is a complex term that has synonyms or accompanying terminology in related studies. Some of these are: diversity, pluralism, ethnicity, race, immigration, religion, oppression, minority, dominance, pressure, authority, inequality, equality, age, power, values, norms, status, identity, citizenship, colonization, enlightenment, ethnocentrism, class, discrimination, vulnerability, risk, subordination, disadvantage, inclusion, exclusion, involvement, participation, empowerment, assimilation, neutralization, standard, variety, consciousness, sensitized, desensitized, awareness, ignorance, recognition, inheritance, legitimation, superiority, traditions, dialogue, redistribution of resources, ethic, politic, interculturality, cohesion, conflict, rights, justice, etc.

Treppe, Fu, and Stremmel indicate that the consequences of conflicts, wars, or severe environmental problems, no matter where in the world, affect us as members of multiple cultures. Race, ethnicity, gender, age, religion, occupational status, socio-economic status and family backgrounds define these cultures. The diverse beliefs, perceptions and behaviors (culturally prescribed or expected) influence our participation in society and the different segments of the society. Strategies are needed to enable its members to come to an understanding with one other regardless of their ethnic, national or religious backgrounds; whether we like it or not, it does not matter. The development of a consciousness of the interdependence of events, relations and multiculturalist approach is therefore essential (1993, pp.3-4; 38-39).

The roots of multiculturalism lie deeply in History. Earlier studies were on identity and its link to the construction of nations, the dominance of culture and subordination of others. The melting pot of assimilation, oppression, colonization, the embeddedness of culture, power relations, and policies were essential points for the emergence of multicultural approaches. The earliest cultural diversity example mentioned is the schooling of native Iroquan children by domineering white settlers and opposition to it in 1744, US. The 1960s and 1970s have shown increasing changes through a shift to multicultural legislation (Canada, Australia and others). Towards the end of the 1980s, multicultural research examples became more systematized 
(a study in Gelsenkirchen, Germany on Turkish children and Mothers Project on the needs of immigrant groups, minority groups in 1985) (Treppteke, Fu, Stremmel, 1993, pp. 1-2).

Current examples are related to the experiences of countries and groups; the entrance of multiculturalism into national and transnational legislation, its application and results, changes and renovations, activities affecting multiculturalism approaches, their acceptability and evaluation (11 September 2001 Twin Towers attack; 2005 London bombing; Christchurch attack, New Zealand,15 March 2019; visual of the body of Syrian Aylan Kurdi on the seashore of Bodrum, Turkey, September 2015; Zero Tolerance in Mexican-US border and separation of children from parents and placement of some of them into foster care or temporary housing, May 2018).

The term had been in use by itself with different connotations, but the earliest examples are under the umbrella of Indian Studies in the US. Richter summarises the roots of the multiculturalism term in the Canadian experience in 1964 with (Sociologist) Charles Hobart's multicultural society and (Slavistic) Paul Yuzyk's multicultural nation terms. Yuzyk, with reference to Hobart, combines both his and Hobart's ideas and refuses to call it Canada's biculturalism, referring to a New Canadian political program as multiculturalism (2011, pp. 35-37).

Contemporary literature on multiculturalism exemplifies the following target groups: immigrant minorities, persons seeking asylum, migrant workers, national minorities, natives, ethno - cultural groups, representers, adults, families, women and more recently children (usually concerning education and traumas), etc. Several mainstream currents of multiculturalist approaches are liberal multiculturalists, Marxist- inspired multicultural critics, Feminist approaches to multiculturalism, Critical multiculturalism, Bristol School, etc.

However, the Convention on the Rights of the Children was the turning point for the inclusion of children in related issues and the establishment of associated institutions, organizations and study groups.

Work by International Sociologia Association - Research Commite 53 Newsletters reveals that the topics of children, childhood and childhoods have gradually become central issues moving from the periphery, from the representation of children by adults, parents, relatives, states, as passive receivers to the actual active human beings. Representations of children have 
been made since the middle of the 1980s and these have increased in the 1990s. Jens Qvortrup reveals that childhood was discovered as a sociological category in the 1980s by Hengst (1981), Jenks (1982), Corsaro (1985), Qvortrup (1985), Zelizer (1985) and Thorne (1987).

Over time, studies have focused on inequality, identity, immigration, mobile individuals within a specific context and stage of life, diversity, discrimination, multilingualism, transnationality, and multiculturality. Individually presented case studies have become grouped and combined after conferences and congresses, and the collaborative attitudes of members of the Sociology of childhood have begun to increase.

Since the 2010s there has been a growing tendency to study and present diverse childhoods and culturally diverse experiences by indicating the danger of a dominant sociological approach which excludes the other sociological situations of the children, such as the importance of the ignored, unheard voices of the children and people studying them.

The years of 2010, and especially 2017, 2018 and 2019 were fruitful years with recently published notes, articles and books on children. These new publications focus overwhelmingly on children through diversity, multiculturality, intersectionality, inequality, globalization, colonization, zero tolerance at borders, Yemeni and Syrian war conflicts, refugee children, social justice, power, violence, and children of other countries among other topics (RC 53, 2019). It seems that, in view of the current unjust, unequal social, political and economic conditions of our era, multiculturalism, children and childhoods will retain their importance in discussions connected to other concepts in our studies.

\section{Referências / References}

RC53-SOCIOLOGY OF CHILDHOOD NEWSLETTERS (2019). International Sociological Association, RC-53 Sociology of Childhood Newsletters. rc53isa.blogspot.com/p/newsletter.html. Retrieved 11.December 2019.

Rıchter, M. V. (2011). Creating The National Mosaic: Multiculturalism In Canadian Children's Literature From 1950 To 1994. Amsterdam. New York: Rodopi.

Treppe, C., Fu, V. \& Stremmel, A. J. (1993). Multiculturalism In Early Childhood Programs. IL: Educational (ERIC) Resources Information Center/EECE. 